\title{
PARQUE LINEAR DO CANIVETE SOB UMA PERSPECTIVA DO DESENHO AMBIENTAL
}

\author{
Giorgia Yoshiko Rossignolo Suzumura
}

Arquiteta e Urbanista pela FAU-USJT; Licenciatura pela FATEC- SP; Professora e Coordenadora do curso técnico de Edificações do IFSP - Campus Itapetininga. E-mail: giorgiayrs@gmail.com

\begin{abstract}
Resumo
Este artigo tem por objetivo analisar através de visita feita ao Parque Linear do Canivete verificando se este segue os conceitos dos projetos de parque lineares quanto ao Desenho Ambiental, além de identificar a recuperação e melhorias ocorridas in loco por sua implantação e os problemas identificados no local e registrados em fotos quanto ao gerenciamento e manejo do parque.
\end{abstract}

Palavras chave: Parque Linear do Canivete, gerenciamento, manejo, corredores verdes, desenho ambiental.

\section{CANIVETE LINEAR PARK UNDER A PERSPECTIVE OF ENVIRONMENTAL DESIGN}

\begin{abstract}
This article aims to analyze the visit made by the Parque Linear do Canivete to make sure it follows the concepts of linear park projects on the Environmental Design, and for identify the recovery and improvements have taken place on the spot by its implementation and issues identified in the local and recorded in photos about the park management.
\end{abstract}




\section{INTRODUÇÃO}

Este artigo é resultado de um trabalho feito para a disciplina de Desenho Ambiental no Programa de Pós-Graduação da Faculdade de Arquitetura e Urbanismo da Universidade de São Paulo, aula esta ministrada pela professora doutora Maria de Assunção Ribeiro Franco.

Como proposta da disciplina, primeiramente, foram estudadas algumas referências bibliográficas para melhor entendimento sobre os diversos assuntos abordados no âmbito do desenho ambiental, com isso, em aula, foram feitas algumas apresentações sobre os levantamentos bibliográficos analisados e, sendo assim, houve um maior e melhor entendimento sobre esta linha de pesquisa.

Após a análise dos conceitos bibliográficos levantados, alguns estudos de casos foram levantados pela professora para que os alunos da disciplina pudessem analisar e propor medidas de melhorias para os casos.

Um dos estudos de casos escolhidos para ser analisado foi o Parque do Bispo situado próximo a Serra da Cantareira que atualmente encontra-se ainda em execução.

Próximo a este parque encontra-se o Parque Linear do Canivete, já executado e muito comentado, com isso, atraindo ainda mais a atenção para a sua análise de projeto e visão de melhorias.

E esse foi um dos motivos que visou a idealização deste artigo, verificar a análise do projeto do parque linear do canivete analisando se este segue os conceitos de desenho ambiental e como está a situação do local com a sua implantação, verificando assim se foram executadas melhorias no entorno após a implantação do parque. 


\section{PARQUE LINEAR DO CANIVETE}

O Parque Linear do Canivete está situado à Avenida Deputado Cantídio Sampaio e Avenida Hugo Ítalo Merigo no Jardim Damasceno, Brasilândia na cidade de São Paulo. Este bairro originou-se de um desmembramento de sítios e chácaras que havia no início do século XX. Os sítios, que antes existiam, com o tempo foram tornando-se loteamentos irregulares. Nos anos 90 a infraestrutura de comércio, bancos e serviços começaram a se estabelecer, acentuando-se sua expansão a partir de 2007.

O bairro apresenta deficiência no sistema de transporte, devido às vias inadequadas e estreitas. Destaca-se a baixa qualidade de vida e precariedade das moradias, com uma taxa de criminalidade alta, ocasionada principalmente pelo tráfico de drogas.

O projeto deste parque linear faz parte do projeto 100 parques da prefeitura de São Paulo, baseado nas diretrizes do Plano Diretor Estratégico, o Programa 100 Parques para São Paulo trata da expansão de áreas verdes com os seguintes objetivos:

$\diamond \quad$ construir um banco de terras públicas prestadoras de serviços ambientais;

$\diamond \quad$ iniciar um plano de adaptação ao novo cenário de mudanças climáticas.

O critério de escolha das localizações para implantação dos futuros parques deste programa foi embasado na identificação de áreas públicas existentes, assim como áreas ambientalmente frágeis, principalmente concentradas nos extremos sul e norte do município, bem como aquelas produtoras de água e de fundos de vale.

Sobre a implantação do Parque Linear Canivete, na região da Cantareira, o objetivo principal deste foi a recuperação de um quilômetro do córrego e de suas margens, além da proteção destas, a readequação do sistema de esgoto e de iluminação pública, de pavimentação das ruas e construção de passeios e calçadas e plantio de árvores.

A área localizada no Jardim Damasceno era ocupada por dois grandes assentamentos irregulares, um na encosta e outro junto ao córrego onde cerca de 600 famílias viviam em situação de risco, estas famílias foram removidas para possibilitar a recuperação da área. 
O projeto do Parque contava com dois playgrounds, cinco quiosques, áreas de atividade física adequadas para a terceira idade, pequena arquibancada, mesas e bancos, praça-mirante, pista de skate, quadra poliesportiva, campo de terra, áreas gramadas para atividades múltiplas e pista de caminhada.

O desenho do parque do Canivete demonstra a sua preocupação e intenção de recuperar uma área degradada pela ocupação irregular e precária, além de tentar impedir o avanço das construções em áreas de risco em encostas e córrego e proteger a Serra da Cantareira.

Para tratarmos do âmbito do desenho ambiental do projeto do parque do canivete, antes de tudo deveremos abordar alguns conceitos que demonstram a situação anteriormente encontrada na área em questão para analisarmos o projeto do parque e sua proposta de implantação.

Como já foi relatada, a área que atualmente encontra-se o parque linear do canivete era uma área onde se encontravam habitações irregulares e precárias em áreas de risco, encosta e córrego.

Na foto abaixo é possível notar a pressão que a ocupação irregular fazia na paisagem e degradava a área do córrego e arredores.

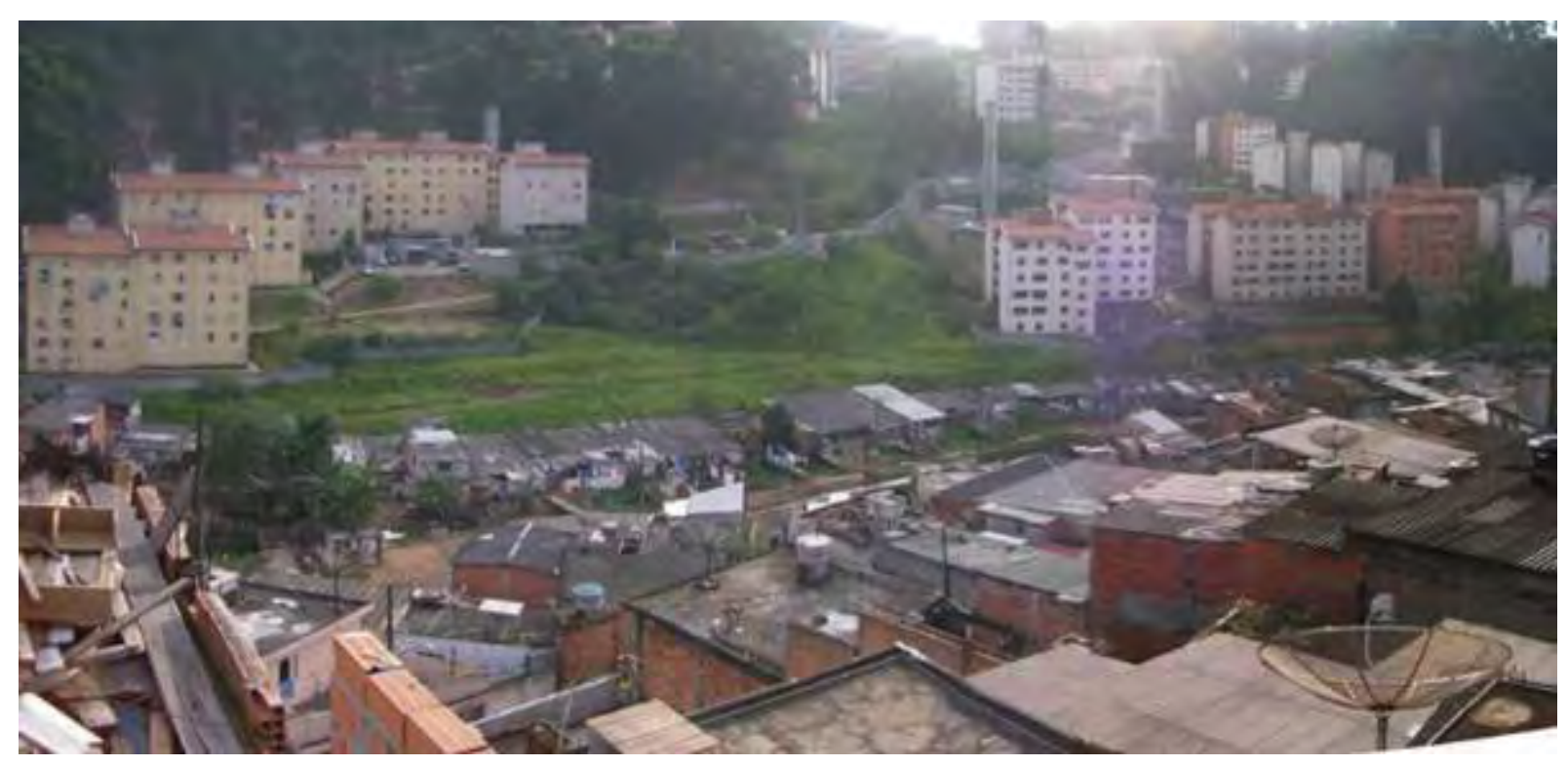

Figura 1: panorama anterior: Favela sobre o córrego. Fonte: SVMA - 2011 


\section{Revista LABVERDE}

O local apresentava um processo de urbanização acelerado e completamente desordenado, apresentando construções precárias, ilegais e geralmente edificadas com restos de madeira, materiais construtivos ou com blocos assentados sem reboco.

A enorme densidade de construções era interligada apenas por vielas estreitas, sem nenhuma área livre e verde entre elas.

Além disso, este local tratava-se de uma ocupação que se não fosse colocado um limite físico para o crescimento das suas habitações irregulares e desordenadas, esta poderia acabar chegando ao limite dos resquícios da Mata Atlântica, situada na Serra da Cantareira conforme podemos ver nas imagens abaixo.

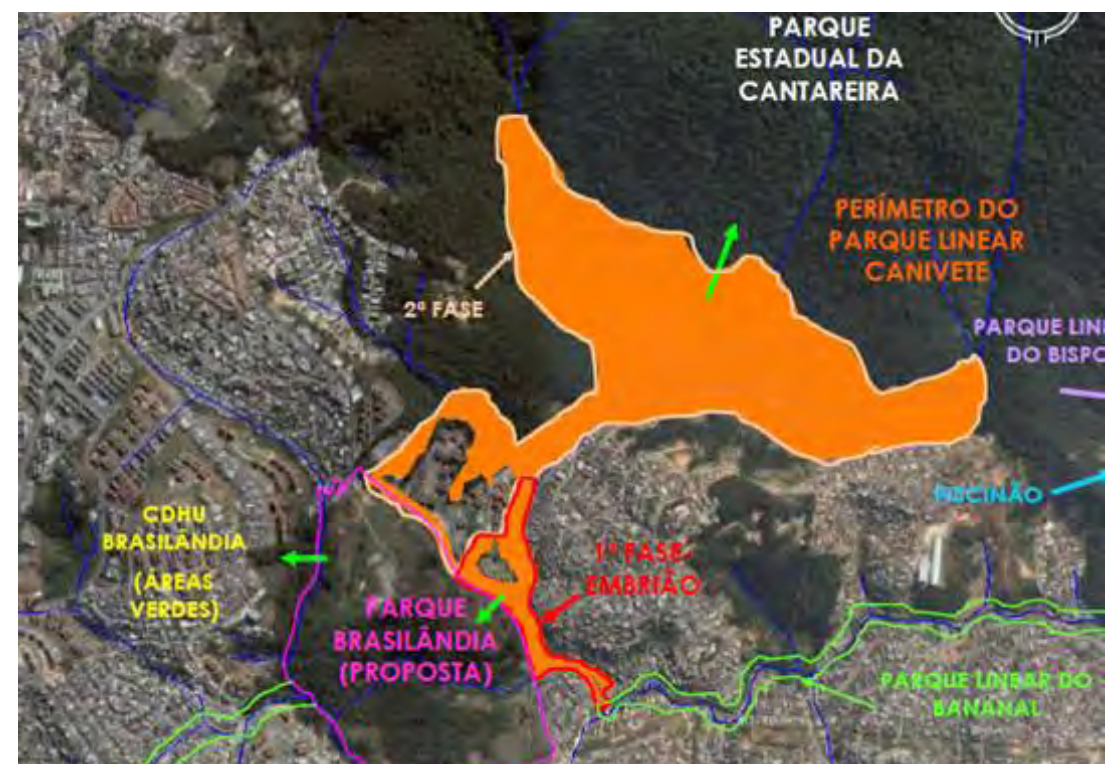

Figura 2: relação entre 0 Parque Linear do Canivete e a Serra da Cantareira - Fonte: SVMA - 2011

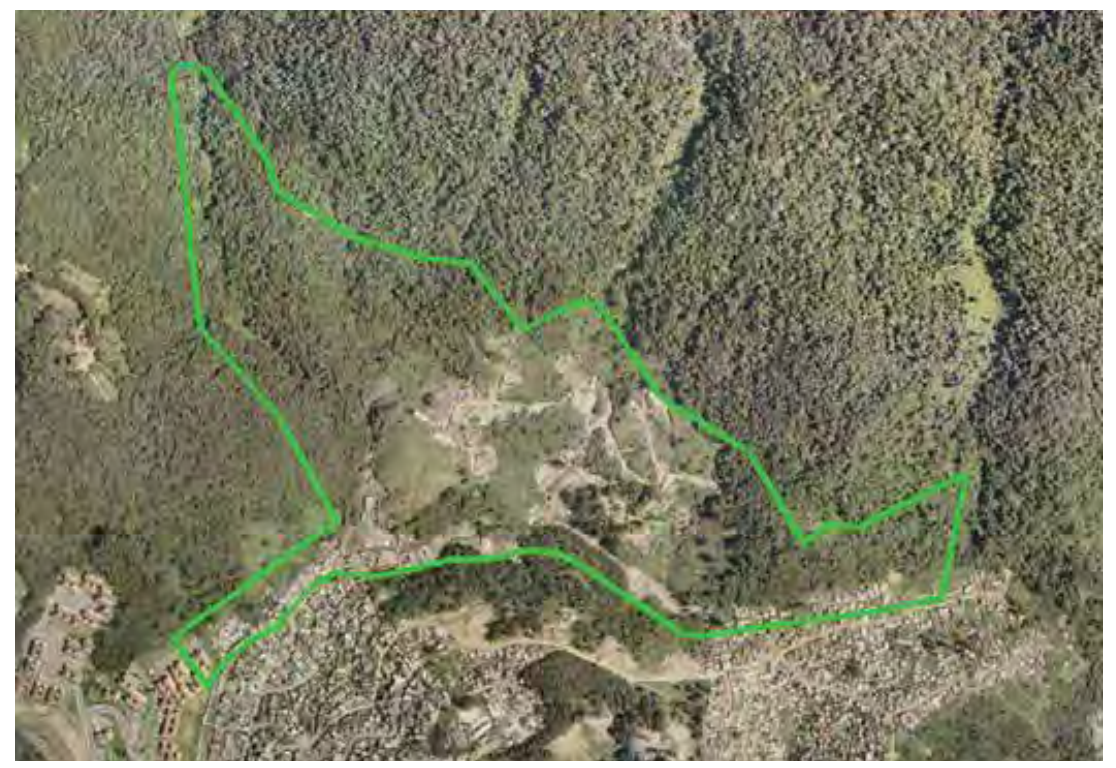

Figura 3: perímetro do Parque Linear do Canivete Fonte: SVMA - 2011 
A característica do local se dava por uma ocupação irregular em área pública, onde se encontravam uma alta concentração de habitações precárias (barracos e autoconstrução) em área de risco e APP (Área de Preservação Permanente).

As habitações promoviam baixa qualidade de vida para seus moradores, onde não existia coleta de lixo e esgoto e os detritos eram despejados diretamente no córrego.

De acordo com HOUGH, a forma urbana é resultado de um constante e dinâmico processo evolutivo, determinado tanto pelos processos naturais, quanto pelos humanos, com suas forças econômicas, políticas, demográficas e sociais.

FRIEDRICH, evidencia que o que tem sido observado são legislações restritivas quanto a proteção de mananciais e ocupação de áreas ambientais"(...)"A conseqüência deste ato são invasões de área, loteamentos irregulares, depósitos de lixo clandestinos, entre outros. Ao introduzir as restrições do uso do solo é necessário que a legislação dê alternativa econômica ao proprietário da terra ou o município deve comprar a propriedade".

Vendo isso, a solução para evitar tais conseqüências, a prefeitura de São Paulo visou propor um parque linear para a área do córrego do Canivete, que entrou no Programa dos 100 parques, visando minimizar o impacto gerado na área, melhorando a qualidade do córrego e da mata, garantindo assim a desocupação das construções irregulares na área propondo uma solução que valorizasse o meio ambiente e a paisagem, além de garantir uma melhoria de vida para a população local, com a utilização do parque para as pessoas que vivem no entorno.

Em meio urbano, a mata ciliar pode muitas vezes minimizar o processo de poluição, contendo, filtrando e purificando a água. Além disto, uma mata ciliar preservada pode contribuir para a contenção dos processos erosivos nas encostas íngremes que contornam os cursos d'água. (FRIEDRICH, 2007, p. 87)

O conceito de corredor é considerado um dos elementos fundamentais da estrutura da paisagem no domínio da disciplina da Ecologia da Paisagem (...). (FRIEDRICH, 2007, p. 91) 
BARTALINI, constata que a ideia de associar rios a áreas verdes não é nova. Os urbanistas Saturnino de Brito, Ulhôa Cintra e Prestes Maia propuseram parques ao longo do Tietê. Antes deles, em 1918, Barry Parker propôs um cinturão verde junto aos rios. E, em 1950, quando surgiram os planos para retificação do Pinheiros, Robert Moses tentou convencer as autoridades da importância de manter uma área verde ao longo do rio.

\section{DESENHO AMBIENTAL}

Segundo FRANCO (2001), o Desenho Ambiental em sua visão interativa com diversas áreas do conhecimento, tendo à disposição tecnologias de ponta, os novos instrumentos para projetos ambientais, representa uma mudança radical na arte de projetar.

A linguagem do Desenho Ambiental tem por base os princípios de desenho responsáveis pela ecologia ou pela geração de oportunidades de suprir necessidades urbanas em função dos recursos existentes, inclui conceitos de processo e mudança, tais como: a economia do meio, a educação ambiental e a valorização do meio ambiente, que integre o homem aos processos naturais.

Parque Linear, por suas características associadas à rede hídrica, deve atender a finalidades paisagísticas e ecológico-ambientais, além das de lazer e sociabilidade.

Segundo o relatório 2 dos instrumentos Legais Necessários à Implantação de Parques Lineares da Secretaria do Verde e Meio Ambiente da Prefeitura de São Paulo, o artigo 106, Parque Linear é definido como:

intervenções urbanísticas que visam recuperar para os cidadãos a consciência do sítio natural em que vivem, ampliando progressivamente as áreas verdes .

A recuperação da consciência do sítio natural, por sua vez, é uma diretriz que deve ser atrelada a programas de educação ambiental.

O Parque Linear se caracteriza fundamentalmente como uma intervenção urbanística associada à rede hídrica e por isso tem características diferenciadas de um parque convencional e que tem como objetivos: 
Proteger ou recuperar os ecossistemas lindeiros aos cursos e corpos d'água;

$\diamond \quad$ Conectar áreas verdes e espaços livres de um modo geral;

$\diamond \quad$ Controlar enchentes;

$\diamond \quad$ Prover áreas verdes para o lazer.

Nesse sentido, deve-se sempre buscar a implantação de espaços visando dar uma continuidade a caminhos verdes e à cobertura vegetal e arborização ao longo do curso hídrico, combinando espaços onde a zona equipada pode ter maior área, se assemelhando a um parque nuclear convencional, e espaços onde a faixa é mais estreita, limitando-se a áreas de preservação da mata ciliar e caminhos verdes, quando possível. A continuidade no tratamento da paisagem ao longo do curso hídrico visa não apenas a recuperação ambiental, mas também a valorização dos cursos d'água como elemento estrutural.

Por isso o desenho ambiental tem a proposta de zonas de amortecimento ou buffer zones para preservação das margens dos rios, onde as matas ciliares são aquelas que protegem os corpos d'água, mantendo a biodiversidade ao longo dos córregos. Essas áreas de vegetação nativa à beira de rios cumprem função relevante ao impedirem o assoreamento das represas e dos reservatórios, causado pela erosão do solo a seu montante.

De acordo com VALERI E SÊNO, para a integração dos aspectos jurídicos e técnicos referentes aos corredores ecológicos, é necessária a conceituação jurídica de alguns termos:

$\diamond \quad$ Área de preservação permanente: área protegida, coberta ou não por vegetação nativa, com a função ambiental de preservar os recursos hídricos, a paisagem, a estabilidade geológica, a biodiversidade, o fluxo gênico de fauna e flora, proteger o solo e assegurar o bem estar das populações humanas.

$\diamond \quad$ Unidade de conservação: espaço territorial e seus recursos ambientais, incluindo as águas jurisdicionais, com características relevantes, legalmente instituído pelo Poder Público, com objetivos de conservação e limites definidos, sob regime especial de administração, ao qual se aplicam garantias 
adequadas de proteção.

$\diamond \quad$ Manejo: todo e qualquer procedimento que vise assegurar a conservação da diversidade biológica e dos ecossistemas;

$\diamond \quad$ Recuperação: restituição de um ecossistema ou de uma população silvestre degradada a uma condição não degradada, que pode ser diferente de sua condição original;

$\diamond \quad$ Restauração: restituição de um ecossistema ou de uma população silvestre degradada o mais próximo possível da sua condição original;

$\diamond \quad$ Zoneamento: definição de setores ou zonas em uma unidade de conservação com objetivos de manejo e normas específicos, com o propósito de proporcionar os meios e as condições para que todos os objetivos da unidade possam ser alcançados de forma harmônica e eficaz;

$\diamond \quad$ Plano de manejo: documento técnico mediante o qual, com fundamento nos objetivos gerais de uma unidade de conservação, se estabelece o seu zoneamento e as normas que devem presidir o uso da área e o manejo dos recursos naturais, inclusive a implantação das estruturas físicas necessárias à gestão da unidade;

$\diamond \quad$ Zona de amortecimento: o entorno de uma unidade de conservação, onde as atividades humanas estão sujeitas a normas e restrições específicas, com o propósito de minimizar os impactos negativos sobre a unidade;

Corredores ecológicos: porções de ecossistemas naturais ou seminaturais, ligando unidades de conservação, que possibilitam entre elas o fluxo de genes e o movimento da biota, facilitando a dispersão de espécies e a recolonização de áreas degradadas, bem como a manutenção de populações que demandam para sua sobrevivência áreas com extensão maior do que aquela das unidades individuais.

De acordo com FERREIRA E MACHADO, os corredores verdes constituem uma componente importante da Estrutura Ecológica, consistindo num instrumento eficaz de requalificação ambiental de territórios degradados e ecologicamente sensíveis. As re- 
des de Corredores Verdes são espaços livres lineares que ligam grandes áreas não lineares ou grandes manchas de espaços naturais, constituindo sistemas de espaços, planejados, projetados e geridos para diversas finalidades, incluindo objetivos ecológicos, recreativos, culturais, estéticos e produtivos, compatíveis com o conceito de sustentabilidade.

A Rede de Corredores Verdes pode, não só proteger os recursos existentes, como também compatibilizá-los com a atividade humana, contribuindo para uma melhor qualidade da paisagem e de vida da população que tem como objetivos fundamentais:

$\diamond \quad$ A delimitação de áreas com elevado valor ecológico cultural e paisagístico;

$\diamond \quad$ A definição de uma rede de corredores verdes com ramificações no tecido urbano;

A proteção dos recursos e a sua compatibilização com a atividade humana;

$\diamond \quad$ Contribuir para uma melhor qualidade da paisagem e de vida da população.

As Redes de Corredores Verdes em ambiente urbano deverão permitir a integração de áreas de maior valor ecológico numa estrutura desenhada e organizada, criando novas componentes e potenciando ligações através dos subsistemas territoriais fundamentais que funcionam como infra-estruturas:

$\diamond \quad$ Infra-estrutura azul (circulação da água);

$\diamond \quad$ Infra-estrutura verde (produção de biomassa);

$\diamond \quad$ Infra-estrutura cultural (paisagem e elementos culturais);

$\diamond \quad$ Infra-estrutura de mobilidade sustentável (não motorizada). 


\section{UMA PERSPECTIVA DO DESENHO AMBIENTAL}

Analisando o projeto do Parque Linear do Canivete, nota-se que este não segue as diretrizes básicas do desenho ambiental. Como se pode notar pelo projeto e visita ao local, o objetivo foi dar vida às margens do córrego, pavimentando-as e propondo área de caminhada, recreação e esportes, mas sabe-se que isso não uma proposta de recuperação da paisagem pelo desenho ambiental.

Antes de qualquer intervenção e proposta deveria haver uma preocupação maior com os resquícios da mata atlântica, o córrego em si com o seu desenho e extensão e principalmente pela sua recuperação e do entorno.

De acordo com a proposta do desenho ambiental ao longo do córrego do Canivete deveria existir um corredor de mata ciliar ao longo das margens para garantir a conservação e proteção do ambiente e biodiversidade da mata atlântica, criando assim uma buffer zone ou zonas de amortecimento, e aí sim, depois destas poderiam ser criadas as áreas de esporte, lazer e recreação para os moradores do entorno, garantindo assim uma faixa de proteção entre o córrego, a mata atlântica e a urbanização

De acordo com BONILHA, as matas ciliares são responsáveis pela filtragem superficial dos sedimentos carregados pela chuva, bem como pela estabilização das margens dos rios, minimizando a erosão natural do solo, ao mesmo tempo abastecem permanentemente os cursos d'água com matéria orgânica.

Na proposta do parque linear do Canivete tratou-se da recuperação e preservação de uma Área de Preservação Ambiental com alto índice de degradação ambiental, o parque funciona como barreira entre a APP e o núcleo habitacional, garantindo assim o saneamento do curso d'água, como o nível de qualidade das águas e recuperação das APPs, urbanizar as áreas com assentamentos precários, melhorar a qualidade de vida reconfigurando o traçado urbano de acordo com proposta de implantação de áreas voltadas ao lazer e esporte para a população local.

Mas, na proposta de recuperação da área onde deviam remover as construções precárias e irregulares sobre o córrego o projeto de implantação do parque foi muito bem sucedido. Obviamente é nítida a recuperação do local, o projeto do Parque Linear do Canivete pode não seguir a risca os conceitos de desenho ambiental para parques lineares, mas com certeza melhorou e muito a região e com isso levou uma melhor 
qualidade de vida a população local proporcionando lazer, esporte e cultura, além de garantir com o parque uma barreira para interromper o avanço da urbanização em direção a Serra da Cantareira onde temos resquícios da mata atlântica na cidade de São Paulo.

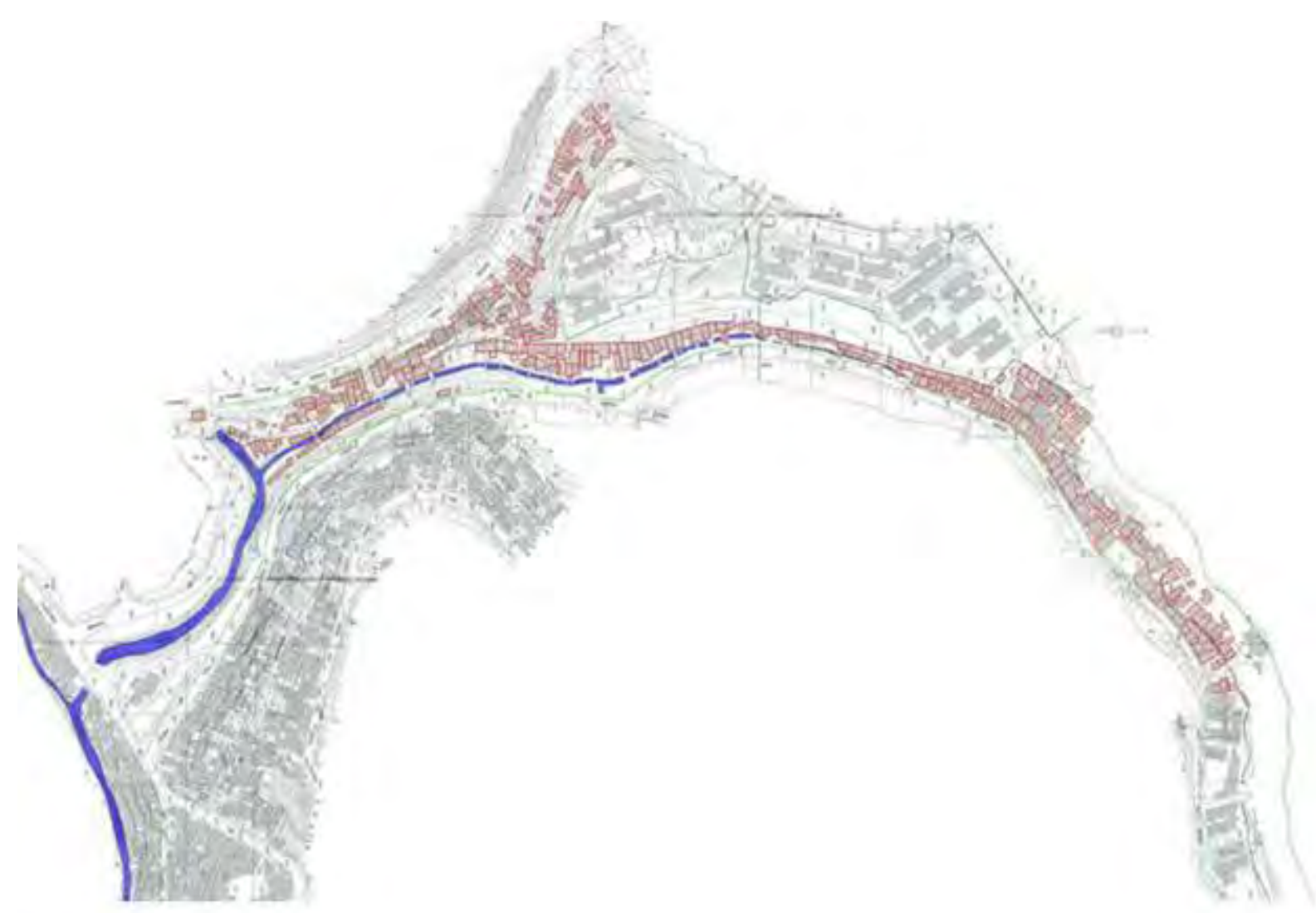

Canivete

Figura 4: ocupação em áreas de risco, encosta e córregos. Fonte: SVMA - 2011 


\section{Revista LABVERDE}

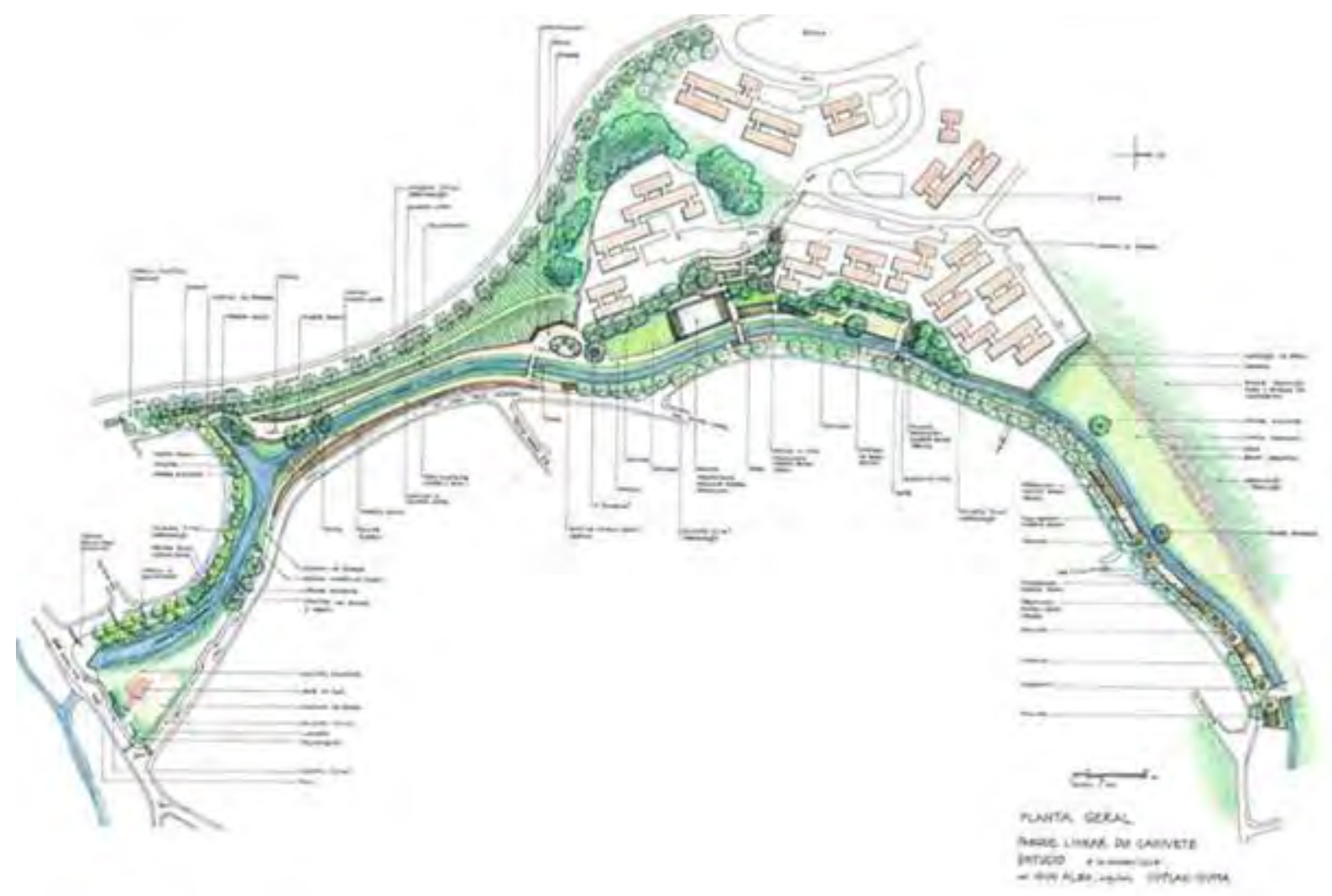

Figura 5: projeto do parque após remoção do risco. Fonte: SVMA - 2011

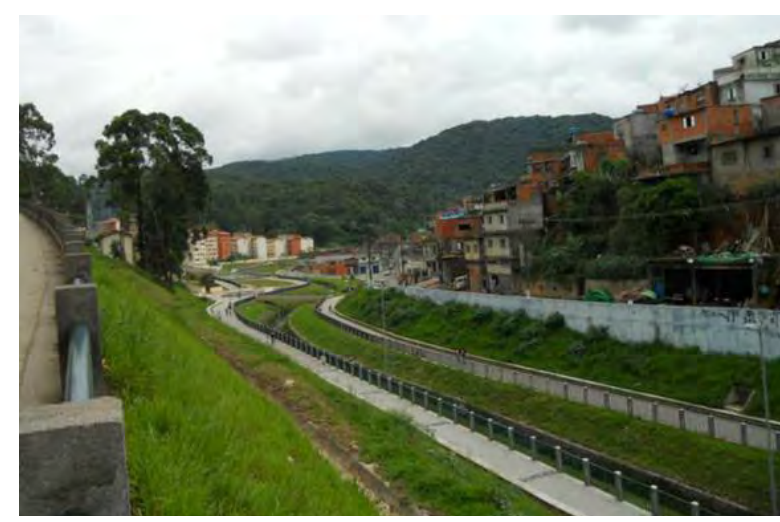

Figura 6: vista geral Parque Linear e a Cantareira. Foto: SVMA - 2011

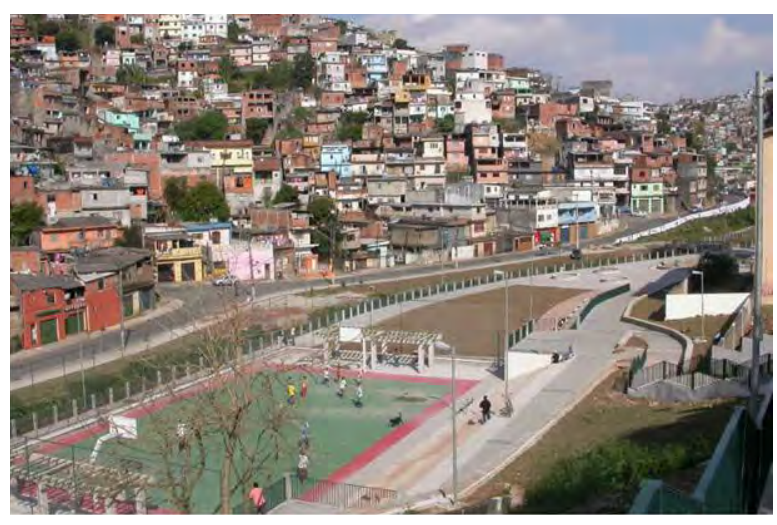

Figura 7: vista geral parque e entorno. Foto: SVMA - 2011 


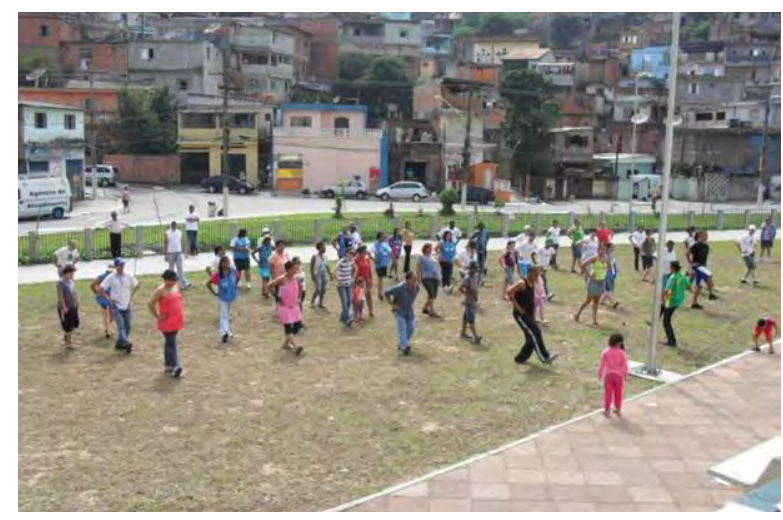

Figura 8: Canivete - Feira da Saúde 2010. Foto: SVMA - 2011

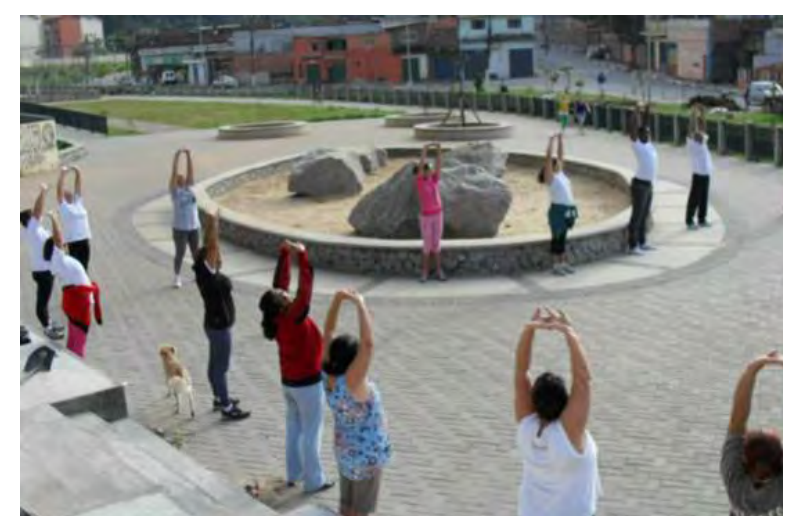

Figura 10: cotidiano caminhada matinal UBS. Foto: SVMA - 2011

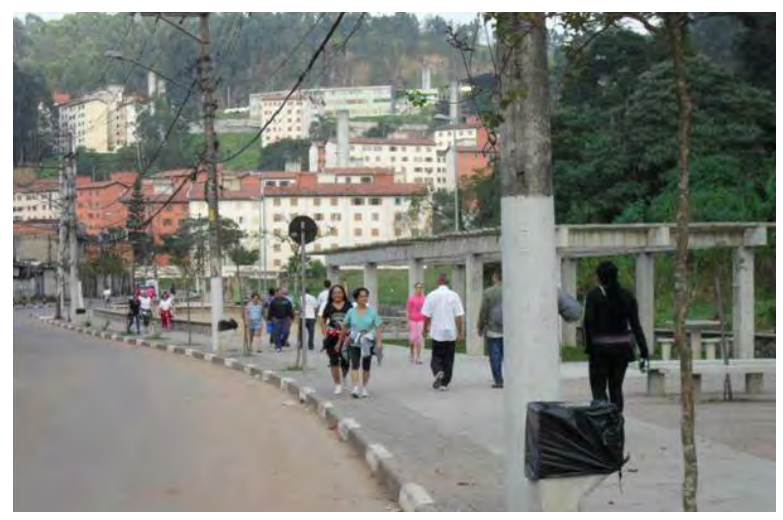

Figura 9: cotidiano caminhada matina UBS início. Foto: SVMA - 2011

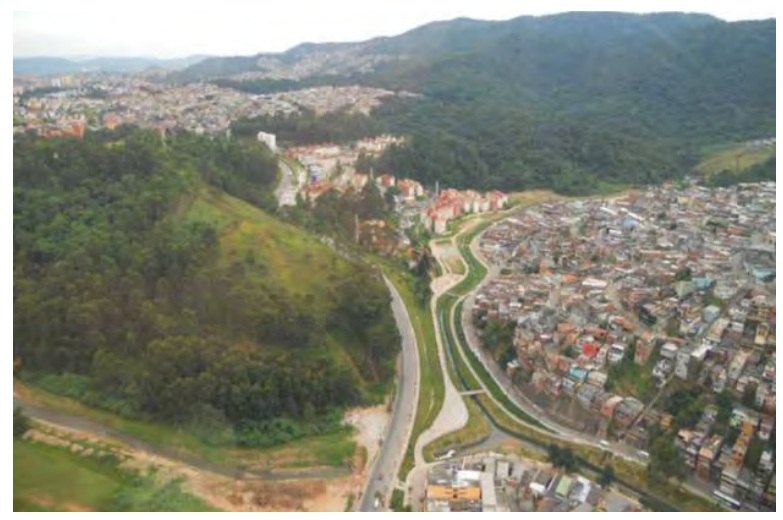

Figura 11: vista aérea - impacto positivo na região. Foto: SVMA - 2011

\section{PROBLEMAS DE GERENCIAMENTO E MANEJO DO PARQUE LINEAR DO CANIVETE}

Em visita ao parque linear do canivete pôde-se notar a falta de gerenciamento e manutenção do parque, ficou óbvio que não se pode pensar apenas em fazer o projeto, mas sim se deve garantir que o mesmo possa se sustentar e manter uma paisagem e infra-estrutura adequada.

BONILHA, cita que é muito importante tomar as medidas adequadas para a disposição dos resíduos sólidos e campanhas de educação ambiental para a conservação da qualidade da água. 


\section{Revista LABVERDE}

Verificou-se in loco que o uso é mais voltado para o esporte pelo uso da quadra onde muitas pessoas encontravam-se. O maior problema diagnosticado foi à falta de conscientização ambiental pelos usuários, pois o local encontrava-se sujo, com deposição de resíduos ao longo das margens do rio e até mesmo dentro do próprio, e também principalmente a falta de fiscalização e gerenciamento do Parque Linear do Canivete para garantir o pleno funcionamento e objetivo desteOutro fator relevante aos problemas encontrados no local foi a proximidade das construções ao longo do córrego, além de ser encontradas construções irregulares na margem do rio.

Para visualizar tais evidências relacionadas acima, foram registradas fotos abaixo que mostram os problemas encontrados in loco para análise da implantação, utilização e gerenciamento do parque.

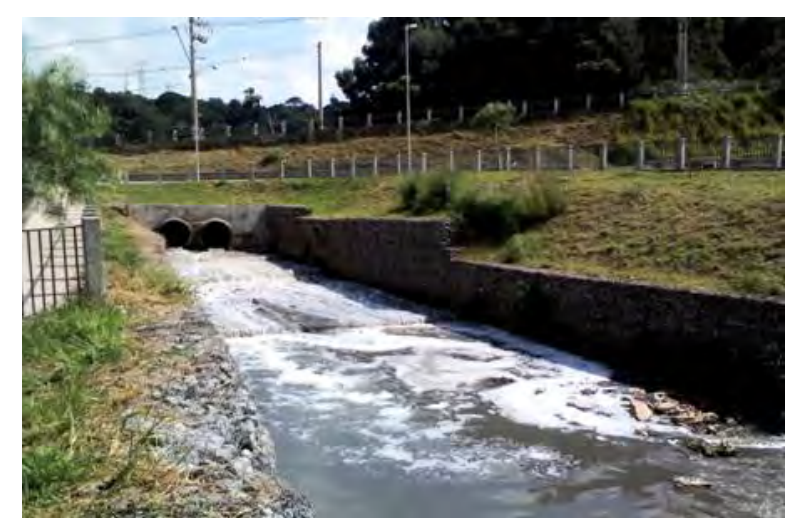

Figura 12: deságue do córrego do Bananal canalizado. Foto: Giorgia Suzumura - abril/2012

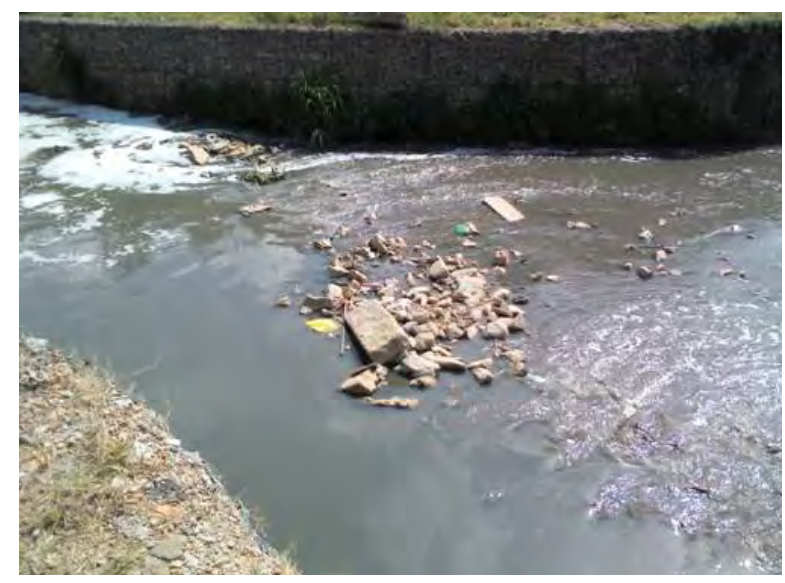

Figura 14: vista dos resíduos despejados no córrego do Canivete. Foto: Giorgia Suzumura abril/2012

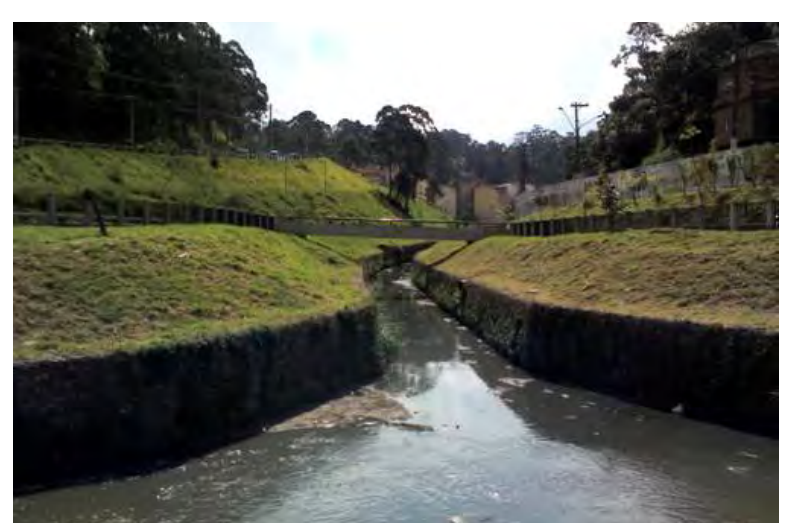

Figura 13: vista da chegada do córrego canalizado. Foto: Giorgia Suzumura - abril/2012

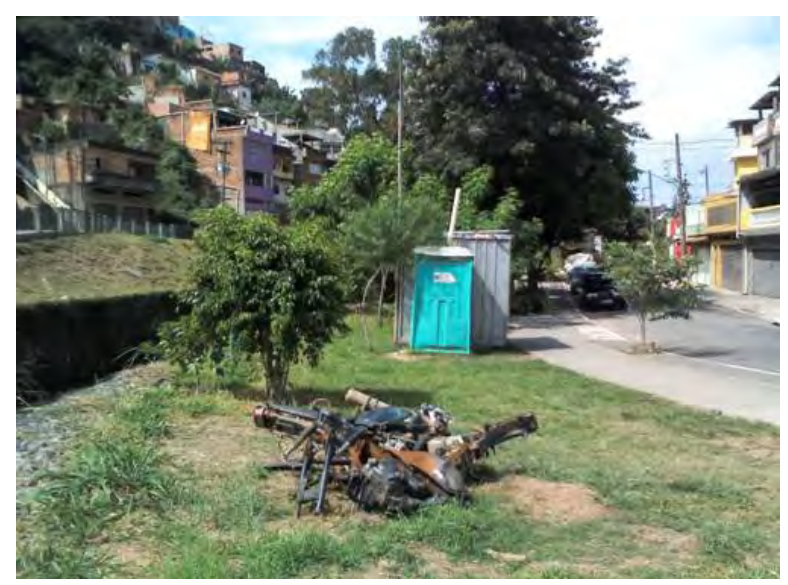

Figura 15: margem do córrego do Canivete com despejo de resíduos. Foto: Giorgia Suzumura abril/2012 


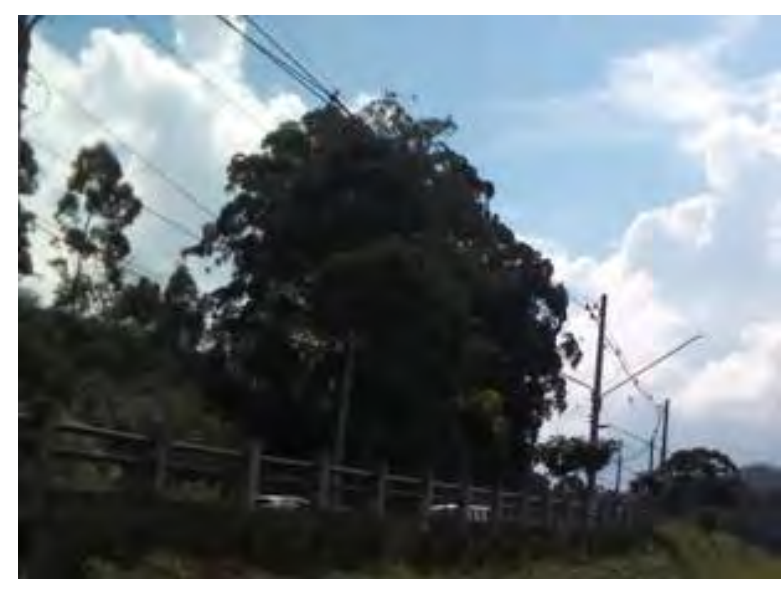

Figura 16: Parque Linear do Canivete. Foto: Giorgia Suzumura - abril 2012

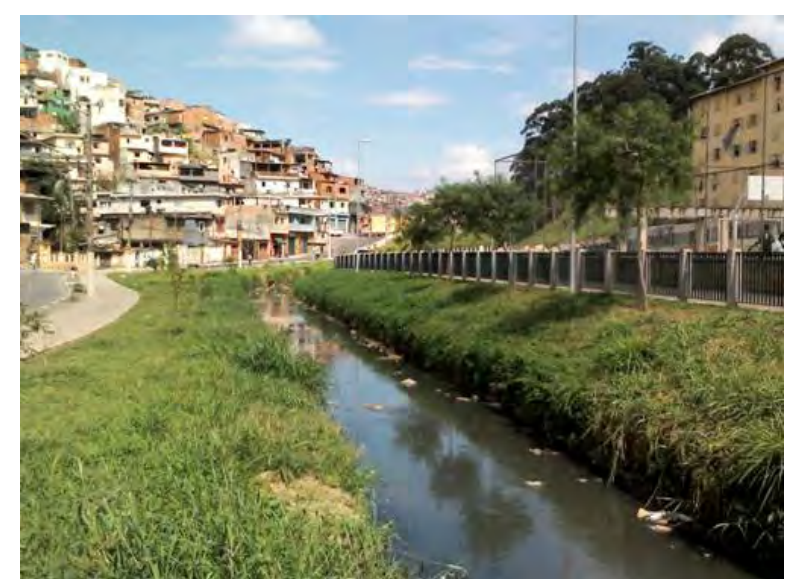

Figura 18: vista do córrego entra as habitações precárias e irregulares e as habitações sociais. Foto: Giorgia Suzumura - abril 2012

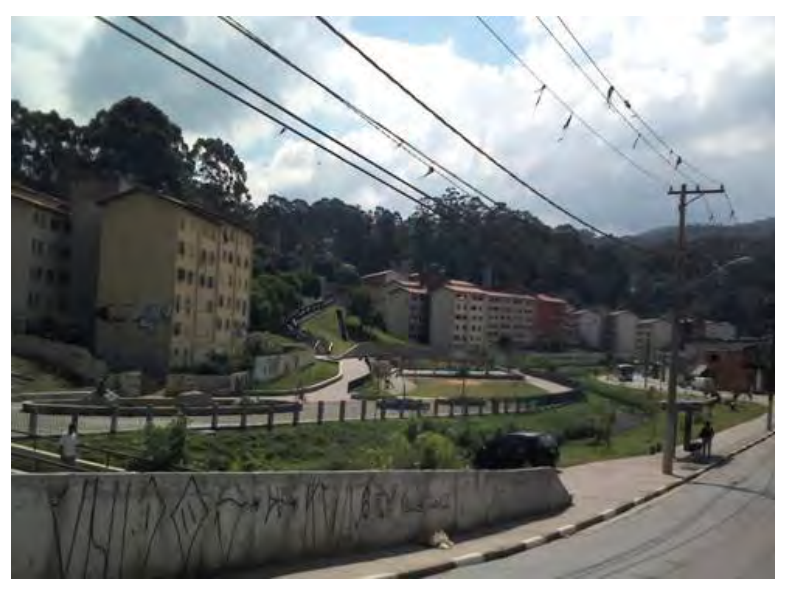

Figura 17: vista do Parque Linear do Canivete com muros pichados e carro estacionado em local impróprio. Foto: Giorgia Suzumura - abril 2012

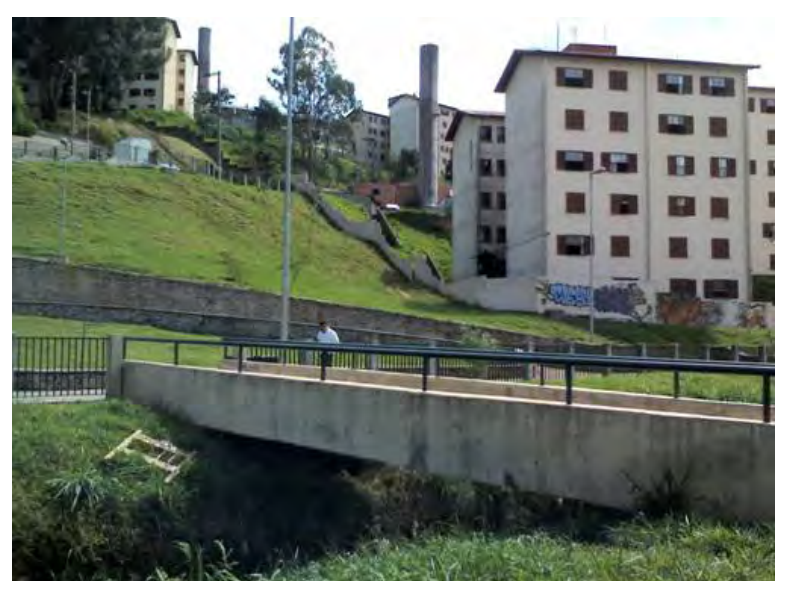

Figura 19: passarela sobre o córrego e cabeceira de cama jogada às margens do rio. Foto: Giorgia Suzumura - abril 2012 


\section{Revista LABVERDE}
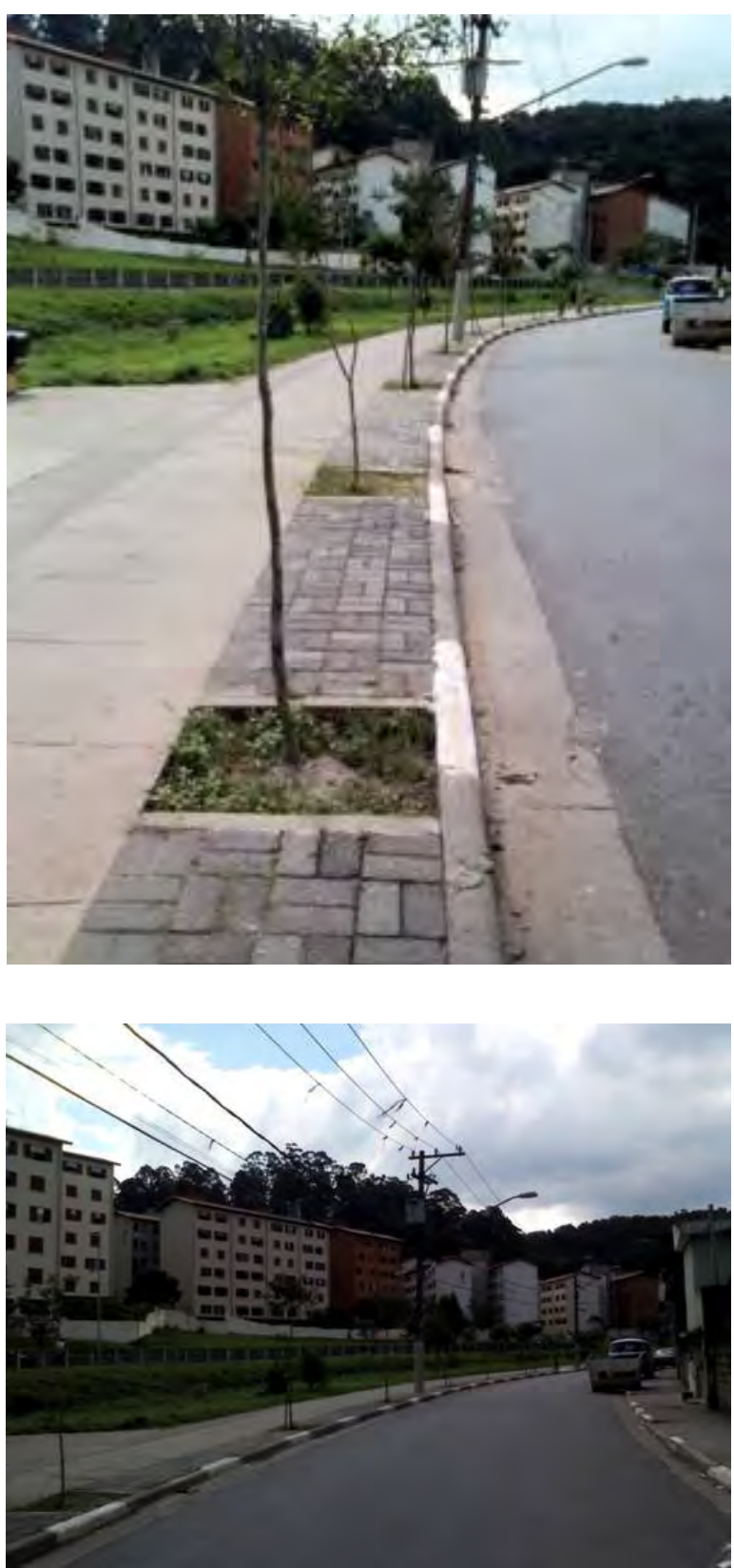

Figura 21: vista das habitações sociais muito próximas ao córrego. Foto: Giorgia Suzumura abril 2012.
Figura 20: pavimentação do Parque Linear. Foto:

Giorgia Suzumura - abril 2012

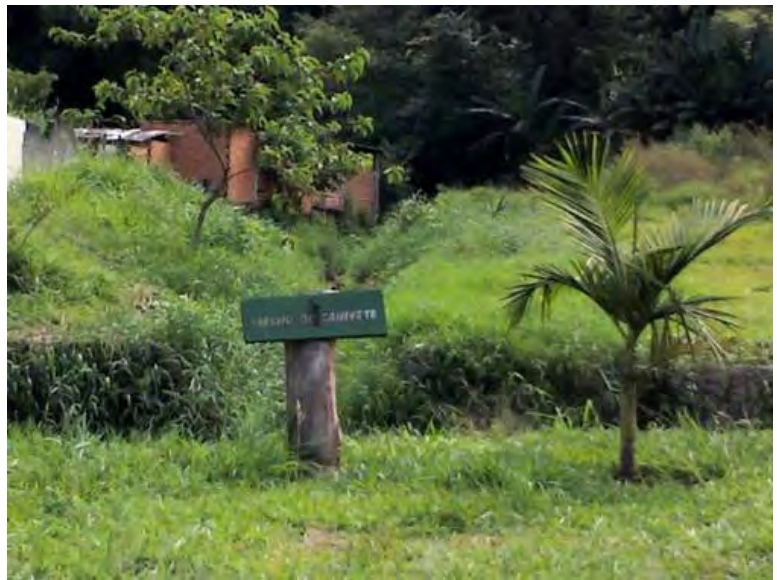

Figura 22: vista do riacho do canivete com construção irregular ao fundo. - Foto: Giorgia Suzumura - abril 2012 


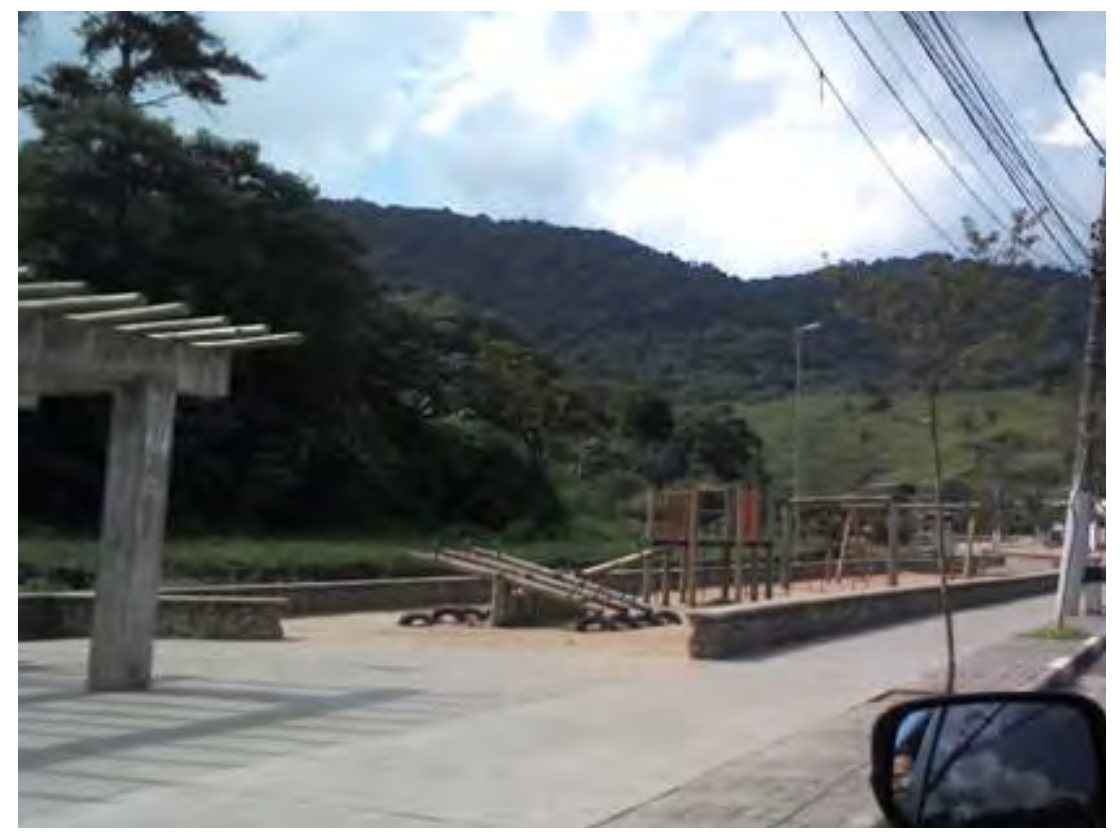

Figura 23: vista do playground do parque linear e ao fundo a serra da Cantareira. Foto: Giorgia Suzumura abril 2012-05-20

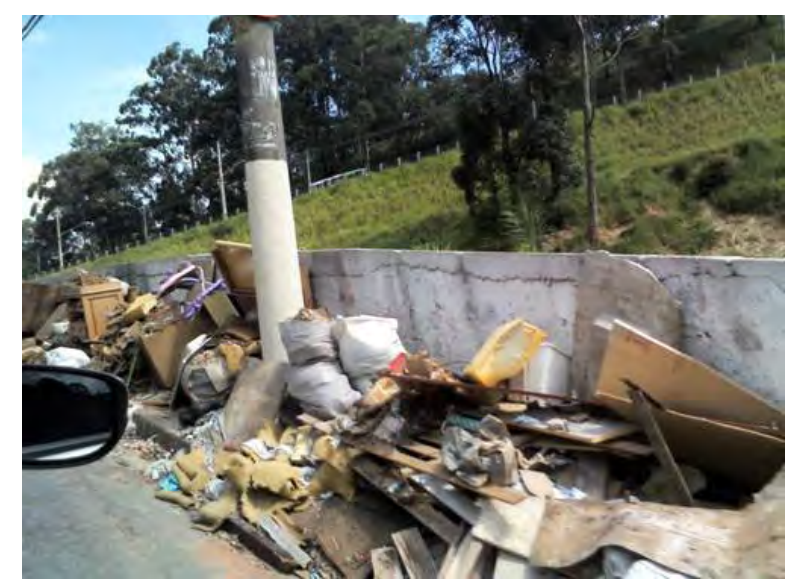

Figura 24: passagem impedida do passeio público pelo depósito de lixo no local. Foto: Giorgia Suzumura - abril 2012.

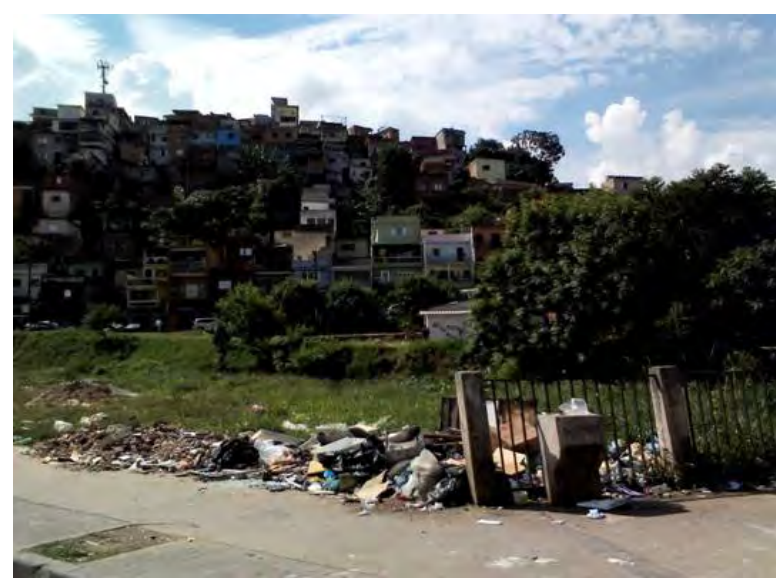

Figura 25: Vista da degradação pelo despejo de lixo ao logo do passeio público e margens do córrego. Foto: Giorgia Suzumura - 2012.

O que ficou claro na visita in loco ao Parque Linear do Canivete é que não adianta somente executar o projeto de parque lineares e melhorias para recuperação de áreas, mas sim deve haver uma gestão pública que considere a capacidade do poder público executivo em equipar e manter os parques lineares, sendo este a subprefeitura ou então a Secretaria do Verde e Meio Ambiente, e sem dúvida, deve haver uma conscientização das pessoas que utilizam o local para manter ao longo do tempo o que foi proposto desde o inicio. A cultura da população do entorno deste local deve ser melhorada para que várias gerações possam aproveitar as melhorias feitas pela implantação do projeto do Parque Linear do Canivete visando tanto a parte social, ambiental, cultural, lazer, esportes e entre outros. 


\section{CONCLUSÃO}

Analisando este parque linear como recuperação de uma área degradada, o projeto foi realmente importante para a melhoria da região. A proposta deste parque linear não remete exatamente aos conceitos de um projeto de desenho ambiental, mas no intuito de melhorias para as questões levantadas, este foi bem sucedido.

O projeto do parque poderia ter seguido os conceitos de desenho ambiental quanto as propostas de revegetações, recuos das construções, matas ciliares como zonas de amortecimento ao córrego, preservação do mesmo e áreas permeáveis ao longo do parque, mas em visita ao local notamos que isso não foi bem seguido. Mas é importante relatar que diante das situações verificadas anteriormente por pesquisas e levantamento do local, hoje este se encontra bem melhor, a implantação do parque linear do canivete garantiu um uso para esporte, lazer e cultura para a população e é claro uma melhor da qualidade de vida para todos que vivem e desfrutam do seu entorno.

Lembrando também que ficou nítida a falta de gerenciamento e manejo do Parque Linear do Canivete, necessitando mais atenção dos órgãos competentes e das pessoas que utilizam para manter a qualidade e funcionalidade do mesmo.

Antes

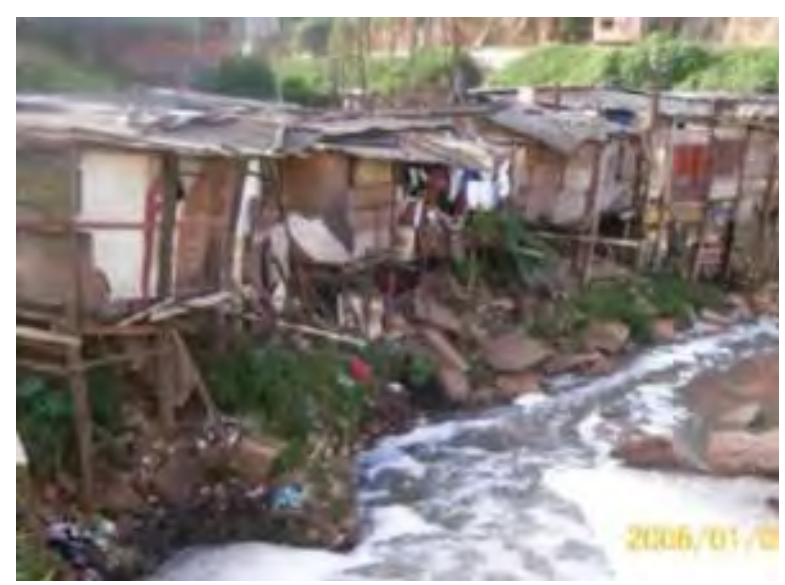

\section{Depois}

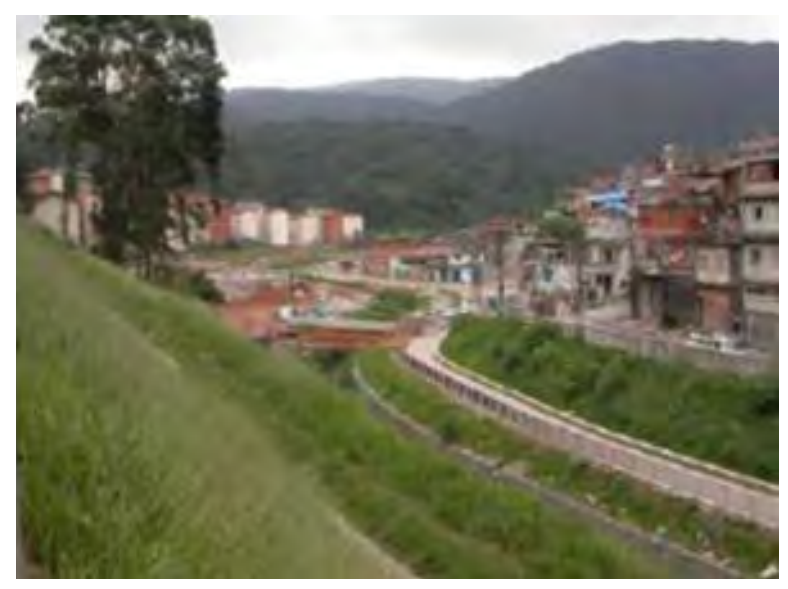

Figuras 26 e 27: Fonte: http://www.slideshare.net/chicomacena/intervenes-em-reas-de-risco-no-municpio-de-so-paulo. Acessado em 20 de abril de 2012. 


\section{REFERÊNCIAS BIBLIOGRÁFICAS}

BARTALINI, Vladimir. Os córregos ocultos e a rede de espaços públicos urbanos. São Paulo: Arquitextos, 2009.

BONILHA, Iraúna. A água e os rios na cidade: Elementos para o projeto ecológico da paisagem. Paisagem e Ambiente - Ensaios. São Paulo: FAUUSP, n.22, p. 172-179, 2006.

FRIEDRICH, Daniela. A visão ambiental no planejamento e gestão de parques lineares em áreas de fundo de vale urbana. In: $\mathrm{O}$ parque linear como instrumento de planejamento e gestão das áreas de fundo de vale urbanas. Porto Alegre, 2007. p. 66-100. Dissertação (Mestre em Planejamento Urbano e Regional) - Faculdade de Arquitetura, Universidade Federal do Rio Grande do Sul.

FERREIRA, José Carlos; MACHADO, João Reis. Infra-estruturas verdes para um futuro urbano sustentável. O contributo da estrutura ecológica e dos corredores verdes. Revista LabVerde: $n^{\circ} 1,2010$.

FRANCO, M. A. R. . Desenho Ambiental uma Introdução à Arquitetura da Paisagem com o Paradigma Ecológico. $2^{\mathrm{a}}$. ed. São Paulo: Annablume, 2008. v. 01. $224 \mathrm{p}$

FRANCO, M. A. R. . Planejamento Ambiental para a Cidade Sustentável. $2^{\mathrm{a}}$. ed. São Paulo: Annablume, 2001. v. 01. $296 \mathrm{p}$

HOUGH, Michael. Naturaleza y Ciudad. Planificación Urbana y Processos Ecológicos. Barcelona, Gustavo Gili, 1998, 308p.

SECRETARIA DO VERDE E MEIO AMBIENTE. Instrumentos Legais Necessários à Implantação de Parques Lineares. São Paulo, 2006.

SECRETARIA DO VERDE E MEIO AMBIENTE. Parque da Borda da Cantareira. São Paulo, 2011. 
VALERI, Ségio; SÊNO, Mirela. A importância dos corredores ecológicos para a fauna e a sustentabilidade de remanescentes florestais.

http://www.slideshare.net/chicomacena/intervenes-em-reas-de-risco-no-municpio-deso-paulo. Acessado em 20 de abril de 2012. 